\title{
Wnętrza w polskim filmie fabularnym lat 60-tych jako źródło wiedzy i punkt odniesienia dla współczesnych projektów architektonicznych
}

\author{
Agata Gawlak \\ https://orcid.org/0000-0002-6234-7953 \\ agata.gawlak@put.poznan.pl
}

\section{Magda Matuszewska \\ https://orcid.org/0000-0003-1133-3807 \\ magda.matuszewska@put.poznan.pl}

Zakład Architektury Usługowej i Mieszkaniowej, Instytut Architektury, Urbanistyki

i Ochrony Dziedzictwa, Wydziat Architektury, Politechnika Poznańska

\begin{abstract}
Streszczenie: Celem artykułu jest zwrócenie uwagi na relację pomiędzy trendami wzorniczymi lat 60-tych, na przykładzie filmu polskiego, a współczesnymi trendami we wzornictwie i projektowaniu mebla. Odwołanie się do filmów z okresu lat 60-tych, jako jednego z istotnych źródeł wiedzy o wnętrzach tamtego okresu, ma stanowić pretekst do dyskusji na temat ponadczasowości ówczesnych projektów. W szczególności, uwzględniając kontekst polityczny i okres PRL. Jednocześnie celem jest pokazanie, w jaki sposób wykorzystywać można źródła filmowe w innych dziedzinach nauki, w ramach badań interdyscyplinarnych, poprzez analizę obrazu filmowego dokonaną przez architekta. Film fabularny jest w więc istotnym uzupełniającym inne, źródłem wiedzy o formach i wnętrzach architektonicznych.
\end{abstract}

Słowa kluczowe: film fabularny, wnętrza, design, wzornictwo, meble, lata 60-te, architektura wnętrz

Fikcja jest tym, co pozwala nam lepiej zrozumieć rzeczywistość [R. Topor]

\section{Obraz filmowy w percepcji architekta}

Dla architekta ważny jest obraz. Szkic, rysunek, schemat. Kompozycja dzieła i jego kontekst. Przenikanie. Forma, struktura, światło, kolor.

Film w ocenie architekta stanowi przede wszystkim sekwencję obrazów. Obrazów jako śladów minionych epok. Zapisów obarczonych często sytuacją polityczną, społeczną, determinującą proces powstawania filmu. Zapisów naznaczonych również percepcją twórców. Wydaje się, że ocena dzieła filmowego wymaga od architekta pokory, bowiem musi on uznać skończone dzieło filmowe, by móc dalej dokonać interpretacji, oceny, i na tej podstawie tworzyć swoje dzieła. Z drugiej strony domniemana wrażliwość architekta na zapis przestrzeni, architektury i miejsc prawdopodobnie sprawia, że obie dziedziny (projektowanie architektoniczne oraz film) są sobie bliższe, w kontekście wzajemnego czerpania z własnych osiągnięć. Architektura stanowi tło dla filmowanych wydarzeń, nieraz stanowiąc pierwszy plan, a film stanowi zapis architektury w czasie i przestrzeni, będąc czymś więcej przecież niż dwuwymiarowa fotografia. Dzięki zapisom filmowym oglądamy dzisiaj dzieła architektoniczne, których już po prostu nie ma. To są nie tylko budynki, ale całe fragmenty miast, panoramy miejskie, które zostały w międzyczasie przebudowane, place, ale również wnętrza budynków, mieszkań, etc. 
Co więcej, ten zapis jest trójwymiarowy, sprzężony ze światłocieniem, kolorem i dźwiękiem. Daje tym samym wiedzę, która uzupełnia inne przekazy (dokumenty, fotografie, etc.).

Film jest również narzędziem porządkującym wiedzę, niewątpliwie wartościującym zachodzące zjawiska i pokazującym je w kontekście, którego w czasie bieżącym nie możemy doświadczać. Parafrazując R. Topora w cytacie umieszczonym w podtytule niniejszego artykułu, obraz filmowy, nawet fikcyjny, niewątpliwie przybliża nas poznawczo do rzeczywistości, której nie mamy możliwości w pełni poznać i ocenić w inny sposób.

W konkretnym przypadku, zapis filmowy może, poprzez szerszy kontekst, stanowić pretekst do oceny, a przede wszystkim porównania rozwiązań architektonicznych charakterystycznych dla minionych epok ze współczesnymi osiągnięciami. Bowiem, jak zauważa Grzegorz Królikiewicz już w 1968 r., „nawet bezmyślna kamera interpretuje świat filmowy samym swym położeniem w przestrzeni". Jednocześnie, jak pisze, dalej wskazuje na relatywizm i pełną demokrację w odbiorze dzieła filmowego przez widza, dając nam, niejako przepustkę do interpretacji przestrzeni w kadrze i poza nim, co decyduje o pewnej dyfuzji poetyckiej filmu.

\section{Marzenia a rzeczywistość}

Historyk sztuki i dekorator wnętrz Felicja Uniechowska prowadząca w latach 60-tych w czasopiśmie "Ty i Ja” rubrykę "Moje hobby to mieszkanie" była uważnym świadkiem tego, w jaki sposób w owych czasach żyli Polacy. Opisując ówczesną kulturę mieszkania podkreśla, że cechował ją przede wszystkim niemal całkowity brak możliwości w dążeniu do estetycznej odmienności. Ów indywidualizm osiągany wbrew wszelkim przeciwnościom losu określiła mianem „biedaindywidualizmu”. Pomimo braku szerokiego asortymentu towaru w branży meblarskiej (z reguły były to seryjne produkcje) Polacy i tak potrafili w pomysłowy sposób nadać przestrzeniom, w których mieszkali czy pracowali, odmienny charakter. Felicja Uniechowska odwołując się często w przedstawianych przez siebie mieszkaniach do stylu retro, w konsekwencji propagowała pewnego rodzaju eklektyzm wnętrzarski i łączenie starego z nowym.

W latach 60-tych do głosu doszło młode pokolenie projektantów. Znacznym piętnem na wyglądzie polskiego mieszkania odbiła się z pewnością standaryzacja w przemyśle meblarskim, która znalazła swoje urzeczywistnienie w produkcji mebli prostych i funkcjonalnych, w których żaden element nie mógł być zbyteczny. Czołowymi przedstawicielami projektantów mebli tego nurtu byli Bogusława i Czesław Kowalscy (J. Kowalski 2014), a meble przez nich projektowane stały się mniej lub bardziej pożądanym, ale - co istotne - możliwym do osiągnięcia celem.

Wydaje się, że najtrudniej mieli ci, których aspiracją było mieszkanie czy praca w przestrzeniach nowoczesnych o mocno zindywidualizowanym charakterze. Produkty zagranicznego przemysłu meblarskiego były nieosiągalne, a działający na rodzimym rynku począwszy od lat 50-tych Instytut Wzornictwa Przemysłowego $z$ trudem promował nowoczesne wzornictwo.

\section{Architektura i design lat 60-tych w Polsce}

Dorobek projektowy z dziedziny projektowania architektonicznego i projektowania mebla z okresu połowy ubiegłego wieku (lata 60-te) uznawany jest za ważny i znaczący na całym świecie, w szczególności w kontekście współczesnych trendów wnętrzarskich. Szczególnym uznaniem cieszą się polscy projektanci.

Ponieważ dzisiaj projektanci w sposób szczególny odwołują się w swoich projektach do dzieł powstających w połowie ubiegłego wieku, wnikliwie bada się ówczesne osiągnięcia w dziedzinie designu i architektury. Stanowi to niejako hołd oddawany dokonaniom poprzedników. Tym bardziej, że polskie projekty $z$ tamtych lat uznawane są na świecie za wybitne osiągnięcia. Aktualna tendencja hołdująca architekturze lat 60 -tych staje się tu pretekstem do poszerzenia wiedzy na temat kontekstu, w jakim owa architektura była tworzona.

Część ówczesnych zrealizowanych projektów nie przetrwała upływu czasu, inne nie trafiły nawet do masowej produkcji. Pozostały na szkicach, we wzorcowniach, jako prototypy lub pojedyncze egzemplarze. Przykładem mogą być realizacje ikony polskiego wzornictwa Teresy Kruszewskiej, która samych tylko krzeseł i siedzisk zaprojektowała ponad sto, z czego żaden nie trafił do masowej produkcji. 
Wydaje się, iż aktualny zachwyt osiągnięciami wzorniczymi minionej epoki nie jest chwilowy i pusty, lecz wyraża się w rzeczywistym wykorzystaniu dorobku projektantów z lat 50-tych i 60-tych we współczesnych projektach mebli i wnętrz. Przykładem mogą tu być realizacje projektanta Piotra Kuchcińskiego (Ryc. 1-3), projektującego dla m.in. dla firmy Noti (Ryc. 4-5) czy Tomasza Augustyniaka dla firmy Marbet (Ryc. 6-7).
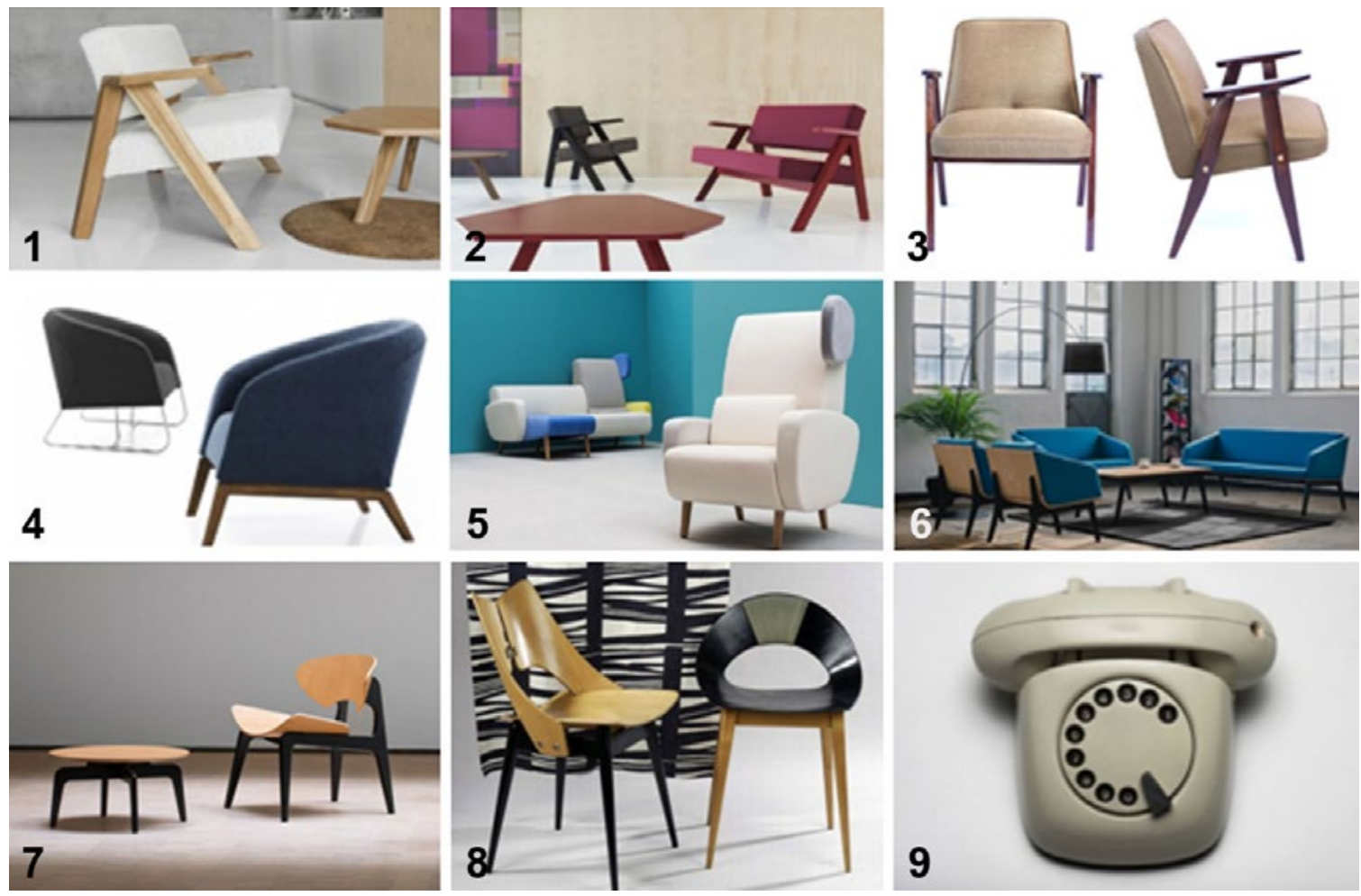

Ryc. 1-2. Kolekcja Clapp dla Noti. 2013 r. Projekt: Piotr Kuchciński. Fotel inspirowany modelem 366 Józefa Chierowskiego Ryc. 3. Źródło: http://www.noti.pl/meble/sofy-i-fotele/clapp.html. Fotel Mula (Ryc. 4.) oraz fotel Teddy Bear (Ryc. 5.). Projekt: Piotr Kuchciński i Michał Wierszyłłowski dla Noti. Kolekcja Fin dla Marbet (Ryc. 6.). Krzesło "Kanu” dla Marbet Style proj. Tomasz Augustyniak, inspirowane wzornictwem lat 60-tych (Ryc. 7.), następca modelu Teresy Kruszewskiej (Ryc. 8.) i Marii Chomentowskiej (Ryc. 9.)

Będąc pod wrażeniem projektów z lat 60-tych (Ryc. 8-9.): foteli Józefa Chierowskiego, Karola Modzelewskiego, mebli Bogusława i Czesławy Kowalskich, Teresy Kruszewskiej, szukamy dalszych powiązań pomiędzy koncepcją, kontekstem a realizacją.

Okres lat 50 i 60-tych, mimo powszechnej kontroli i podporządkowaniu wielu dziedzin życia władzy politycznej, był również czasem bardzo ożywionych i wizjonerskich działań na polu artystycznym i projektowym, równolegle wspieranym poprzez osiągnięcia technologiczne i przemysłowe. W 1950 r. powołano Instytut Wzornictwa Przemysłowego, który programowo wspierał innowacyjne działania. Cechami łączącymi ówczesne wzornictwo była m.in. inspiracja geometryczną abstrakcją oraz ornamentami roślinnymi, lekkie formy, często o opływowych, zaokrąglonych krawędziach (inspiracja technologią kosmiczną). Dużą wagę przywiązywano do ergonomii i wielofunkcyjności.

\section{Film jako źródło wiedzy o architekturze i stylu życia w latach 60-tych}

Źródłem wiedzy o wnętrzach mieszkalnych i usługowych z lat 50 i 60-tych jest m.in. polski film fabularny, w którym odnajdujemy współczesne trendy. Film traktowany jako źródło wiedzy historycznej stanowi ważną bazę danych. Szczególnie dotyczy to gatunku filmów dokumentalnych, które cechuje przede wszystkim zgodność daty i miejsca nagrania z rejestrowanym wydarzeniem. Dla wielu badaczy, kwestia wartości dokumentu jako 
źródła historycznego jest bezsporna. Oryginalność nagrania stanowi o jakości i wierności przekazu informacji dotyczącej np. klimatu epoki, emocji, etc.

Uznaje się, że film stanowi narzędzie do interpretacji minionych epok (W.M. Magidow).

W.M. Magidow zwraca uwagę, iż niemożliwe jest rozpatrywanie filmu bez szczególnej wiedzy na temat okresu, w którym powstał - w tym kontekstu historyczno-politycznego z uwzględnieniem procedur administrowania produkcją na wszystkich etapach powstawania filmu, a nawet postawy społecznej i etycznej samego autora. Ponieważ, jak pisze M. Hendrykowski „ekranowe przedstawienie historii, nawet najbardziej adekwatne, będzie zawsze wersją tej historii". Pisząc dalej o filmie, jako zawierającym w sobie jedynie "cząstkę prawdy", jako architekci w pewien sposób uzurpujemy sobie prawo, by jako tę "cząstkę" przyjąć obraz dokumentujący projekt mebla i pokazujący go w mniej lub bardziej autentycznym kontekście.

Analityczne spojrzenie na dokonania minionych epok i ich wzajemne powiązania, jak pisze architekt Romuald Loegler, wyzwala siłę do pokonywania już wyznaczonych granic.

W tym kontekście, parafrazując Dorotę Skotarczuk, film jest dla architekta traktowany nie w pełni jako źródło historyczne, lecz jako źródło wiedzy potocznej współczesnych o przeszłości i jako oczywisty element procesu dydaktycznego.

Saramowicz przywołuje dokonania, w tym osiągnięcia teoretyczne, architekta Bernarda Tschumiego, który niejako inkorporuje do architektury, jako jeden z pierwszych architektów, inne dziedziny jak dziennikarstwo czy film, czyniąc z tego pretekst do re-definicji zależności przyczynowo-skutkowych jako elementów kompozycji i hierarchii w architekturze. Pisze o tym właśnie sam Saramowicz, wskazując, jako metodę na kwestionowanie ciągłości w architekturze poprzez zastosowanie nowych zasad teoretycznych wynikających choćby z zapożyczenia z teorii filmu. Odnajduje się tu pewne analogie, gdzie architekt poprzez swoją kreację, tworzy scenariusz, osadzony w kontekście jakim jest czas i przestrzeń.

Wszystko to jest dowodem wzajemnych, interdyscyplinarnych powiązań i występujących sprzężeń zwrotnych pomiędzy takimi dziedzinami jak film i architektura.

Obraz filmowy lat 60-tych uznaje się za bardzo osobisty sposób wypowiedzi jego twórców.

W filmie "Mąż swojej żony" (Ryc. 10, 11) w reż. Stanisława Barei z 1961 r. oglądamy wnętrze mieszkania głównych bohaterów, umeblowane w bardzo konwencjonalny sposób. Samo mieszkanie znajduje się w bloku z tzw. wielkiej płyty. Przypuszcza się, że to róg ul. Okrąg i Wilanowskiej w Warszawie. Mieszkanie jest urządzone w dość typowy sposób. Pokój dzienny spełnia zadanie pomieszczenia wielofunkcyjnego, łączącego cechy przestrzeni wypoczynkowej, sypialnianej oraz jadalnianej. Odnosi się wrażenie, że znajdujący się tam stół jest zbyt mały, dodatkowo ustawiony w sposób nie do końca funkcjonalny, niezapewniający wystarczającego komfortu biesiadnikom. Podczas sceny przyjęcia możemy dostrzec zestaw na pozór przypadkowych krzeseł, "nie od kompletu". To co dzisiaj jest trendem, wówczas było koniecznością, a krzesła prawdopodobnie zostały pożyczone od sąsiadów. Łączy je jednak charakterystyczne dla lat 60-tych wzornictwo, są wykonane z drewna, posiadają wąskie nóżki, wysmuklone proporcje, delikatne, łódkowate oparcia. Na myśl przywołują projekty Marii Chomentowskiej i Teresy Kruszewskiej.

W tle dziejącej się w kuchni sceny, oglądamy charakterystyczny kuchenny kredens. Kuchnia jest taką przestrzenią, która najczęściej ulega schematyzacji, i wielu obrazach filmowych przedstawiana jest podobnie, czasem zdaje się szablonowo. Odnosi się wrażenie, że ta drugoplanowość tego pomieszczenia wiąże się ze sposobem postrzegania pomieszczenia kuchni w hierarchii mieszkania. Oglądamy zazwyczaj pojedyncze wiszące szafki, najczęściej jasne. W tle nierzadko pojawia się charakterystyczny masywny kredens.

W filmie "Zbrodniarz i Panna" z 1963 r. (Ryc. 12, 13) charakterystyczne dla epoki elementy wyposażenia tworzą spójną kompozycję i stoją się głównym planem dla sceny, która rozgrywa się poza ekranem. Statyczność całej kompozycji w rzeczywistości zwiększa jeszcze napięcie i potęguje emocje. Całość przypomina skwapliwie wykadrowaną, martwą naturę. Widzimy masywny lecz nowoczesny odbiornik radiowy, stojący na charakterystycznym, delikatnym, smukłym stoliku pokrytym politurą, obok ława ze szklanym blatem i smukłymi nóżkami, na której stoi kryształowa popielnica. Główny charakter scenie nadaje niezwykle finezyjny i nowoczesny fotel, którego siedzisko tworzy swoistą kolebkę, z podłokietnikami w kształcie uszu. Dekoracją są tu obszywane guziki. Wysmakowana całość stanowi wręcz kwintesencję nowoczesności.

Mebel bywa tłem, dopełniającym kontekst, ale bywa również, że staje się pierwszoplanowym aktorem, chociażby w scenie filmu "Wszystko na sprzedaż” (1968 r.), gdzie rozsuwany stół pokryty fornirem na tzw. wysoki 
połysk, zmienia się w potencjalną gilotynę, narzędzie w rękach bohaterki, które realnie zagraża i wprowadza silne napięcie (Ryc. 14).

Wręcz odczuwalne na skórze zagrożenie powoduje świadomość, w jaki sposób działa mechanizm stołu - jak cienka tafla blatu, z niewielkim oporem przesuwając się po drewnianych szynach, ale za to z dużą siłą, może zranić bohaterkę filmu. Kolor, który pojawia się w filmie wzmacnia przekaz jak np. w scenie w sali kinowej, scenografia oparta na sekwencji kwadratowych modułów w intensywnie karminowym kolorze przywołuje kompozycje malarskie artystów awangardowych z okresu międzywojennego.

W "Małżeństwie z rozsądku" (Ryc. 15) smukłe, fornirowane meblościanki, na zwężających się ku dołowi nóżkach, uzupełniane dekoracją rozpraszających światło kryształowych naczyń, oglądane przez bohaterów, odwołują tęsknoty za nowoczesnością. Ekspozycja, którą widzimy w sklepie meblowym, przypomina do złudzenia scenografię w filmie "Lekarstwo na miłość" (Ryc. 16) - mieszkania architekt Joanny. Znamienne, że ta nowoczesność przejawiająca się w wyposażeniu meblowym mieszkania nie jest spójna z jego stanem technicznym (odpadający sufit), co stanowi być może celny przekaz mówiący o fasadowej roli pewnych elementów wnętrzarskich, które z jednej strony demonstrują światopogląd bohaterów, ich gusta czy modę, ale jednocześnie pozostając w kontraście do realnych możliwości, jeszcze bardziej podkreślają właśnie ów brak nowoczesności i zacofanie czy niedostatek.

Mieszkanie Joanny jest o tyle szczególne, że to co stare (przedwojenna kanapa, stolik) łączy się w bezpretensjonalny sposób z nowym (prosty, nowoczesny fotel). Z racji zawodu wykonywanego przez Joannę widz może odczytać, że taki zabieg jest nawet nie tyle koniecznością, ile wyrazem artystycznych poglądów właścicielki mieszkania.

\section{Podsumowanie}

Wnętrza mieszkań w polskim filmie fabularnym z lat 60-tych pokazywane są w różny sposób, w różnym celu. Niejednokrotnie są to wnętrza ubogie, skromnie wyposażone, co wskazuje na raczej powszechnie panujący w tamtych czasach niedostatek. Często powtarza się motyw pomieszczenia wielofunkcyjnego, w którym bohaterowie jednocześnie pracują, przygotowują i spożywają posiłki, odpoczywają czy przyjmują gości (np. Smarkula, Znaki na drodze, Małżeństwo z rozsądku). Tak potraktowana przestrzeń może symbolizować nie tylko trudną sytuację ekonomiczną, ale i pewnego rodzaju stan tymczasowości.

Ci bohaterowie, z kolei, których oglądamy żyjących w przestrzeniach przypominających współczesne nam mieszkania - z wyodrębnionymi pomieszczeniami przeznaczonymi na odpoczynek, przygotowanie posiłków, pracę - postrzegamy w pewnym sensie jako bardziej osadzonych w danej rzeczywistości, miejscu i czasie. Ich sytuacja materialna wydaje się być bardziej stabilna, a mieszkania w których żyją stanowią - niezależnie od rozgrywających się w tle dramatów czy choćby nadchodzących zmian - metafizyczną przystań, pewien punkt odniesienia. Tak dzieje się choćby w przypadku Siennickich w „Ich dniu powszednim”, rodziny Kłosowiczów w "Beacie" czy Joanny w "Lekarstwie na miłość" (Ryc. 16).

W wielu obrazach filmowych tłem stają się charakterystyczne dla owych czasów detale z motywami folklorystycznymi czy odwołującymi się do estetyki przedwojennej. Mieszkanie-pracownia Kwileckiego w "Małżeństwie z rozsądku czy mieszkanie-pracownia Profesora w "Człowieku z M-3", najwyraźniej zaaranżowane przez jego córkę Agnieszkę, raczej świadczą o wysokim statusie materialnym właścicieli. Willa Kapitana Klementa z "Żony dla Australijczyka" (Ryc 17) pełna jest pamiątek przywiezionych z odległych krajów, zaaranżowanych w mieszkaniu w interesujący sposób. Tak jakby na zindywidualizowanie przestrzeni życia czy pracy stać było tylko niewielu. Podobnie postrzegać można wnętrza skrajnie nowoczesne jak na owe czasy, np. biuro dyrektora w „Pieczonych gołąbkach" (Ryc. 18) - dostęp do nowoczesności był dany jedynie nielicznym. Takie wnętrze stawało się synonimem władzy czy prestiżu jego właściciela.

W każdym z przypadków scenografia stanowi pewną dygresję ze strony twórców, którzy w ten sposób dopowiadają historię swoich bohaterów, uzupełniają ich portrety psychologiczne czy pokazują pozycję społeczną.

W artykule celowo odniesiono się do przykładów obrazów filmowych, które pokazują nowoczesne wzornictwo i nowoczesne przykłady aranżacji wnętrz mieszkalnych. Choć były one trudno osiągalne dla większości czy wręcz niedostępne, pozostawały dla wielu przedmiotem pożądania, synonimem sukcesu czy uosobieniem piękna. 
Niewątpliwie film jest istotnym źródłem wiedzy na temat charakteru i stylistyki wnętrz mieszkalnych dla architekta, zwłaszcza w przypadku, gdy istnieje stosunkowo mało źródeł historycznych na ten temat. Co istotne, pozwala nie tylko na obejrzenie np. mebla w szerszym kontekście całego mieszkania, ale jednocześnie pokazuje sposób jego użytkowania, rolę w kompozycji z innymi elementami wyposażenia wnętrza.
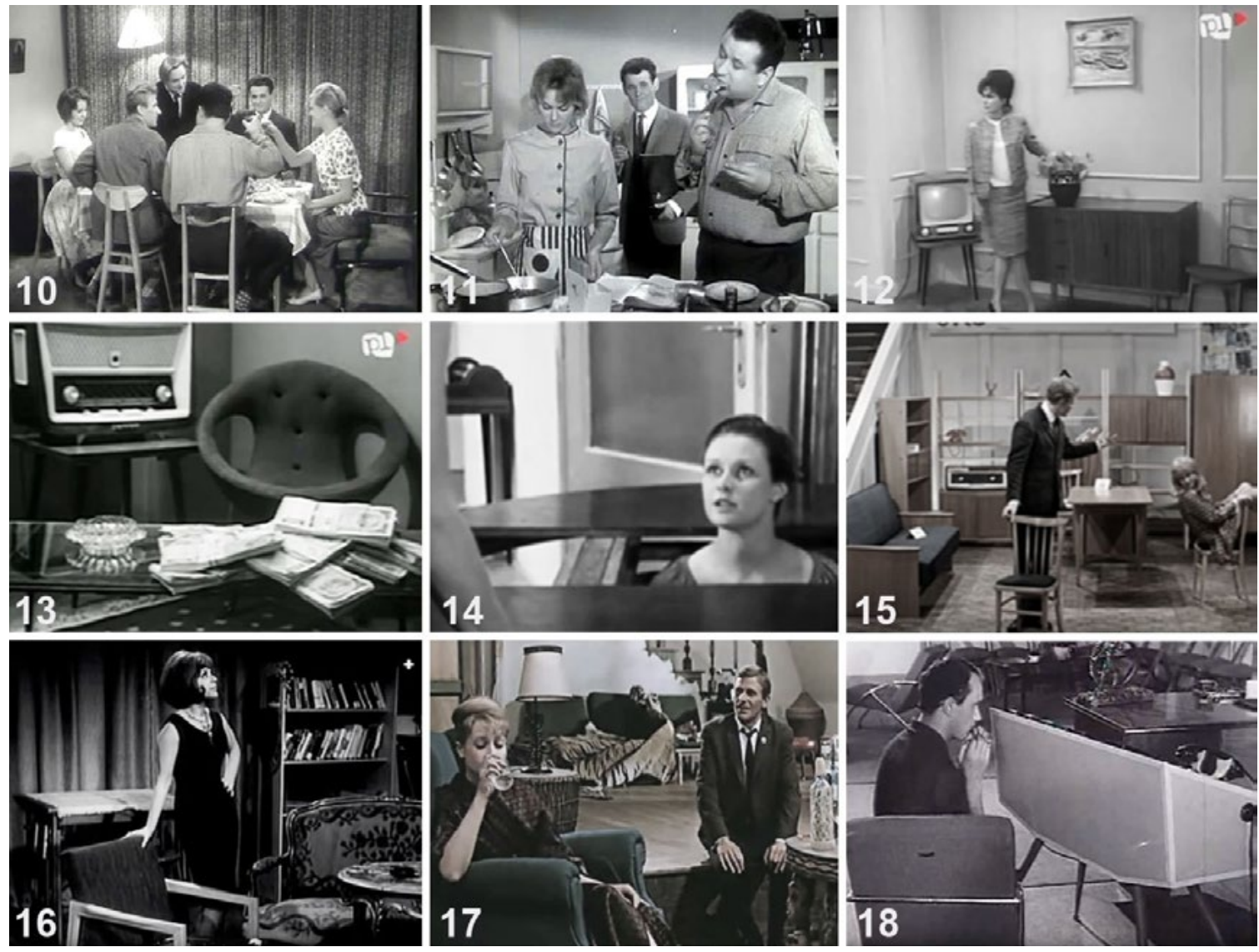

Ryc. 10-11. "Mąż swojej żony” (reż. Stanisław Bareja), Ryc. 12-13. "Zbrodniarz i panna” (reż. Janusz Nasfeter), Ryc. 14. „Wszystko na sprzedaż" (reż. Andrzej Wajda), Ryc. 15. „Małżeństwo z rozsądku” (reż. Stanisław Bareja), Ryc. 16. „Lekarstwo na miłość" (reż. Jan Batory), Ryc. 17. „Żona dla Australijczyka” (reż. Stanisław Bareja), Ryc. 18. „Pieczone gołąbki” (reż. Tadeusz Chmielewski)

\section{Bibliografia}

[1] Erbay M., Modern architecture and cinema: an assessment through iconic buildings. International Journal of Academic Research Part A; 2013; 5(5), 14-23. DOI: 10.7813/2075-4124.2013/5-5/A.2.

[2] Hendrykowski M., Film jako źródto historyczne, Wyd. ars nova, Poznań, 2000, ISBN 83-87433-14-4.

[3] Hendrykowska M. red. nauk., Widziane po latach. Analizy i interpretacje filmu polskiego, Wydawnictwo Poznańskiego Towarzystwa Przyjaciół Nauk, Poznań, 2000, ISBN 83-7063-261-0.

[4] Kowalski J., Meble Kowalskich. Ludzie i rzeczy, Wydawnictwo Dębogóra, Poznań, 2014.

[5] Królikiewicz Grzegorz, Przestrzeń filmowa poza kadrem, Kino, V 1968.

[6] Saramowicz P. Kwartalnik Filmowy 1999, nr 28.

[7] Skotarczak Dorota, Film i media audiowizualne w refleksji polskich historyków, Kultura i historia, 22/2012.

[8] Szelągowska G., Film w warsztacie historyka. Uwagi na marginesie Piotra Witka, Kultura, film, historia. Metodologiczne problemy doświadczenia audiowizualnego, Kwartalnik Historyczny Rocznik CXV, 2008, 1 PL ISSN 0023-5903, Lublin 2005, Wydawnictwo Uniwersytetu Marii Curie-Skłodowskiej, ss. 285. 


\title{
Interiors in the Polish feature film of the 1960s as a source of knowledge and a reference point for contemporary architectural designs
}

\begin{abstract}
The aim of the article is to draw attention to the relationship between the 1960's design trends, based on the example of the Polish film, and contemporary trends in furniture design. The reference to films of the 1960s as one of the crucial sources of knowledge about the interiors of that period is to be a pretext for further discussion on the timelessness of the 1960s designs, taking into consideration the particular political context in the Polish People's Republic. The article, moreover, aims to show how film sources, analysed by architects, can be used in other disciplines of science, within the framework of interdisciplinary research. Summing up, the feature film is an important supplementary source of knowledge about architectural forms and interiors.
\end{abstract}

Keywords: feature film, interiors, design, furniture, 1960's, interior design 